\title{
EXPLORING THE DIFFERENCE BETWEEN RECYCLERS AND NON-RECYCLERS: THE ROLE OF INFORMATION
}

\author{
RAYMOND DE YOUNG \\ The University of Michigan \\ Ann Arbor
}

\begin{abstract}
This article reports on a pilot study which explored how recyclers and non-recyclers differ. Two hundred households were first identified by direct observation over a series of months being either recyclers or non-recyclers. These households were then contacted and ninety-one respondents agreed to answer a series of verbal questions and complete a short written questionnaire. While from a preliminary study, these data are useful in suggesting that recyclers and non-recyclers are similar in their prorecycling attitudes, extrinsic motivation, and the degree to which they viewed recycling as a trivial activity. They differed significantly, however, in the degree to which they required additional information about recycling. Non-recycling respondents indicated a lack of information on how to carry out the activity. The study is also of interest due to the isolation of attitudinal and behavioral aspects of recycling. Since some form of relationship between these two constructs is so pervasive in the literature, the results are conceptually intriguing. Perhaps more important, however, are the practical implications for enabling non-recyclers to change their behavior independently of their attitudes.
\end{abstract}

In addition to accumulating great wealth, an affluent society generates an enormous quantity of solid waste [1,2]. For instance, in 1971 Americans discarded over 125 million tons of solid waste; by 1988 the quantity amounted to over 160 million tons and current projections indicate that by 1990 the amount could top 200 million tons.

The standard waste disposal practice of landfilling, questionable on ecological grounds, is now a politically unacceptable option. Siting new landfills and expanding old ones are difficult tasks. Yet our waste management options are

(C) 1989, Baywood Publishing Co., Inc. 
limited. Of the strategies available only recycling has consistently demonstrated strong grass-roots support. This "low technology" strategy for reducing the need for new landfills has been generally technically successful and often cost-effective. It rates high in most opinion polls, yet its rate of adoption is disappointing in terms of the number of households participating and the amount of the waste stream being recovered. Recycling is used currently to manage only 10 percent of the municipal solid waste stream-while the Environmental Protection Agency's suggested goal is to manage 25 percent of the municipal solid waste stream through recycling and waste reduction by $1992[3]$.

If recycling is to have so significant an effect on our solid waste dilemma, then it must become a commonplace activity. To that end, resource recovery education programs have focused on getting non-participating households to begin recycling voluntarily. These programs often begin with the assumption that non-recyclers somehow differ from recyclers. For instance, non-recyclers are thought to have a less positive attitude about the activity or to believe it to be trivial. This article presents a preliminary exploration of the degree to which this assumption is warranted.

This article focuses on the attitudes held by recyclers and non-recyclers for two reasons. First, attitude research has been at the center of psychology throughout its history [4-7]. More to the point, attitudes have played a large part in the study of conservation behavior $[8,9]$. In fact, much of the sociobehavioral research related to waste reduction and resource recovery has concentrated on correlation recycling-related behaviors to attitudes [10]. Second, many environmental educators concentrate their efforts on awareness and attitude development. For instance, resource recovery education programs of ten attempt to promote recycling through attitude change. This approach has theoretical support. Gray [11], Macey and Brown [12], and Weigel [13] have provided excellent discussions on the development of attitude models of human behavior with an emphasis on environmentally appropriate actions. As Weigel states:

Although definitions vary, there is general agreement that attitudes represent relatively enduring sets of beliefs and feelings about an object which predisposes the attitude-holder to act in a particular way toward that object.

\section{METHODS}

\section{The Setting}

The research reported here focuses on a recycling program that had been in effect for over ten years. This program provided monthly pick-up of waste materials from the curb in front of each resident free to any household willing 
to prepare the materials properly. Residents were asked to hand-sort various waste materials (e.g., newspaper, glass, metal) and place them at the curb-side on a designated collection day.

An established area of the city, composed of approximately 2,266 residences, was chosen as the focus of this study. This area had been involved in the recycling program from its beginning. Recycling behavior was measured by direct observation over a three-month period. An observer rode the collection truck during every run and recorded which houses had put recyclables out on the curb-side. In this area, approximately 19.3 percent of the households were observed to recycle one month out of the three, 12.9 percent recycled two months out of the three and 9.5 percent recycled all three months. Overall, 41.7 percent of the area's households recycled at least once during the three-month period.

\section{The Sample}

For the purpose of this study a household was classified as a recycler if and only if it had used the curb-side recycling service at least once during the three-month observation period. Two hundred households were randomly selected and an attempt was made to contact an adult member of each by telephone. When contacted, the adult was asked to consent to being interviewed about recycling. In households classified as recyclers the caller asked to speak to the adult most involved in the activity. For households initially classified as non-recyclers there was the possibility that the household recycled in a way other than by using the curb-side collection service (e.g., using the city's drop-off recycling center). The survey instrument included checks for this possibility. The results support the initial classification; non-recyclers reported no other recycling activity (apart from a few respondents who said they returned deposit beverage containers to supermarkets).

Telephone contact was made with 146 (73 percent) of the 200 households. Ninety-one adults agreed to be interviewed, (62 percent of those contacted). of these, $32(35 \%)$ were recyclers and $59(65 \%)$ were non-recyclers. Approximately 54 percent of the ninety-one respondents were women $(45 \%$ among recyclers, $59 \%$ among non-recyclers).

\section{The Survey Instrument}

During the interview the respondents were asked to complete a brief survey instrument. This questionnaire assessed recycling activity using a series of (5-point Likert) scales derived from past research on recycling [14, 15] and water demand management [16]. These previous studies explored the multidimensional structure of conservation attitudes, motivations, behaviors, and satisfactions derived. The scales were developed using dimensional analysis 
of survey data from three separate random samples. The current survey instrument also collected information on demographics and recycling experience. ${ }^{1}$

\section{RESULTS}

The five major scales used to explore the differences between recyclers and non-recyclers are presented in Table 1 along with each scale's mean score, standard deviation, and Cronbach's coefficient of internal consistency, alpha.

Table 1. Questionnaire Scales

\begin{tabular}{|c|c|c|c|}
\hline Scale Names and Items Included & Mean & S.D. & Alpha \\
\hline $\begin{array}{l}\text { PRO-RECYCLING ATTITUDE } \\
\text { - Recycling is good because it helps to reduce imports } \\
\text { - I like it when stores carry recycled products } \\
\text { - A good reason to recycle is to reduce the need } \\
\text { for landfills } \\
\text { - It really bothers me to see things go to waste }\end{array}$ & 4.06 & .72 & .58 \\
\hline $\begin{array}{l}\text { FRUGALITY (Satisfaction derived from:) } \\
\text { - Finding ways to avoid waste } \\
\text { - Keeping something running long past its normal } \\
\text { life } \\
\text { - Repairing things rather than throwing them away } \\
\text { - Finding ways to use things over and over } \\
\text { - Saving things I might need someday (boxes, fabric, } \\
\text { wood, etc.) }\end{array}$ & 3.87 & .84 & .84 \\
\hline $\begin{array}{l}\text { EXTRINSIC MOTIVATION } \\
\text { - I'd need a very large monetary incentive before } \\
\text { I'd recycle } \\
\text { - I would recycle only if paid to do so }\end{array}$ & 1.85 & 1.06 & .83 \\
\hline $\begin{array}{l}\text { TRIVIAL } \\
\text { - I would feel funny being the first on my block } \\
\text { to recycle } \\
\text { - Recycling is a hobby which some have time for } \\
\text { and others don't }\end{array}$ & 2.03 & .87 & .49 \\
\hline $\begin{array}{l}\text { PERCEIVED DIFFICULTY } \\
\text { - A problem with recycling is finding a place to put } \\
\text { the stuff } \\
\text { - It's a big nuisance to keep everything separated } \\
\text { for recycling } \\
\text { - I'm never exactly sure what I'm supposed to do } \\
\text { to recycle }\end{array}$ & 2.96 & 1.00 & .62 \\
\hline
\end{tabular}

${ }^{1}$ A copy of the survey instrument may be obtained from the author. 
Table 2. Correlations Among Scales

\begin{tabular}{lcccc}
\hline & $\begin{array}{c}\text { Pro-Recycle } \\
\text { Attitude }\end{array}$ & $\begin{array}{c}\text { Extrinsic } \\
\text { Motivation }\end{array}$ & Trivial & Frugality \\
\hline Extrinsic Motivation & -.49 & & & \\
Trivial & -.51 & .72 & & \\
Frugality & .26 & -.15 & .18 & \\
Perceived Difficulty & -.15 & .21 & .29 & -.03 \\
\hline
\end{tabular}

This coefficient reflects the degree to which a collection of items "hang together." (Since items that group together can be thought of as alternate measures of some abstract "construct," the alpha value can be thought of as a rough measure of "construct validity" $[17,18]$.) The difference in scale mean scores for every pairwise comparison was statistically significant at $p<.02$ (except for the Pro-Recycling/Frugality pair).

These findings suggest that it may be possible to identify component attitudes underlying people's overall attitudes towards recycling. For instance, quite apart from their more or less positive opinion about recycling, respondents may feel constrained by insufficient storage space or may lack information about how to carry out the activity. Furthermore, independent of their attitude about this very specific form of conservation, the respondents may derive satisfaction from frugal behavior in general.

\section{Comparing Recyclers and Non-Recyclers}

It is not uncommon for survey respondents to be classified as conservers or non-conservers based upon their self-report. The study reported here used direct observational data to classify households as recyclers or non-recyclers. Thus, these data provide an opportunity to compare the responses of known recyclers to known non-recyclers. Table 3 shows the means for each group for each of the questionnaire scales. It is noteworthy that the two groups do not have significantly different scores on the Pro-Recycling Attitudinal scale. In fact, they do not differ in their ratings of extrinsic motivation and trivialness, nor of frugality. The recyclers and non-recyclers, however, responded differently to the perceived difficulty of the behavior.

\section{On There Being More Than One Type of Recycler}

The fact that individuals who differed with respect to their recycling behavior had similar mean scores on the attitude scale is in contrast to much of the literature on the attitude-behavior relationship mentioned earlier. Given that attitudes play a central role in much of environmental education, this finding seemed worthy of further exploration. 
Table 3. Mean Scores for Recyclers and Non-Recyclers

\begin{tabular}{|c|c|c|c|c|}
\hline & & Non-Recyclers & Recyclers & $t$-test \\
\hline Pro-Recycling Attitude & $\begin{array}{l}\text { Mean }= \\
\text { S.D. }= \\
\mathrm{N}=\end{array}$ & $\begin{array}{c}4.02 \\
0.59 \\
59\end{array}$ & $\begin{array}{c}4.13 \\
0.40 \\
32\end{array}$ & n.s. \\
\hline Frugality & $\begin{array}{l}\text { Mean }= \\
\text { S.D. }= \\
\mathrm{N}=\end{array}$ & $\begin{array}{c}3.91 \\
0.65 \\
59\end{array}$ & $\begin{array}{c}3.80 \\
0.84 \\
32\end{array}$ & n.s. \\
\hline Extrinsic Motivation & $\begin{array}{l}\text { Mean }= \\
\text { S.D. }= \\
\mathrm{N}=\end{array}$ & $\begin{array}{c}1.87 \\
0.88 \\
59\end{array}$ & $\begin{array}{c}1.81 \\
1.64 \\
32\end{array}$ & n.s. \\
\hline Trivial & $\begin{array}{l}\text { Mean }= \\
\text { S.D. }= \\
N=\end{array}$ & $\begin{array}{c}2.04 \\
0.60 \\
58\end{array}$ & $\begin{array}{c}2.02 \\
1.07 \\
32\end{array}$ & n.s. \\
\hline Perceived Difficulty & $\begin{array}{l}\text { Mean }= \\
\text { S.D. }= \\
N=\end{array}$ & $\begin{array}{c}3.14 \\
0.88 \\
59\end{array}$ & $\begin{array}{c}2.65 \\
1.09 \\
32\end{array}$ & $\begin{array}{l}t=2.28 \\
d f=89 \\
p<.03\end{array}$ \\
\hline
\end{tabular}

Although the sample size in this preliminary study is small, the attitudinal data exhibit enough variation to suggest that one might have a group of recyclers with a "more positive" attitude and another group with a "less positive" attitude (similarly for the non-recyclers). Respondents were classified as less positive about recycling if their score on the Pro-Recycling Attitude scale was equal to or less than 4.2. Respondents were classified as more positive if their score was greater than 4.2 . The cut-off value of 4.2 allows one to place respondents into all four cells shown in Figure 1.

The mean scores for these four groups on the remaining four scales are shown in Table 4. In an effort to better understand these data a series of Two-way Anovas were conducted. Each analysis used the recycler/non-recycler variable and the Pro-Recycling Attitude scale as the independent variables with each of the other scales acting, in turn, as the dependent variable. The attitude scale was significantly related to the Frugality, Extrinsic Motivation, and Trivial scales $(F=4.85, d f=1,87, p<.03 ; F=9.10, d f=1,87, p<.005 ;$ and $F=19.7$, $d f=1,86, p<.001$ respectively). The recycler/non-recycler variable was significantly related to only the Perceived Difficulty scale $(F=5.03, d f=1,87$, $p<.03)$. There were no significant interaction effects.

Two of the cells in Figure 1 seem to comport with the attitude-behavior model: the non-recycler holding a less positive attitude and the recycler holding a more positive attitude. Non-recyclers who hold a less positive attitude about the activity may be thought to be either completely unaware of the issues surrounding recycling or reluctant to participate unless coerced or encouraged. 


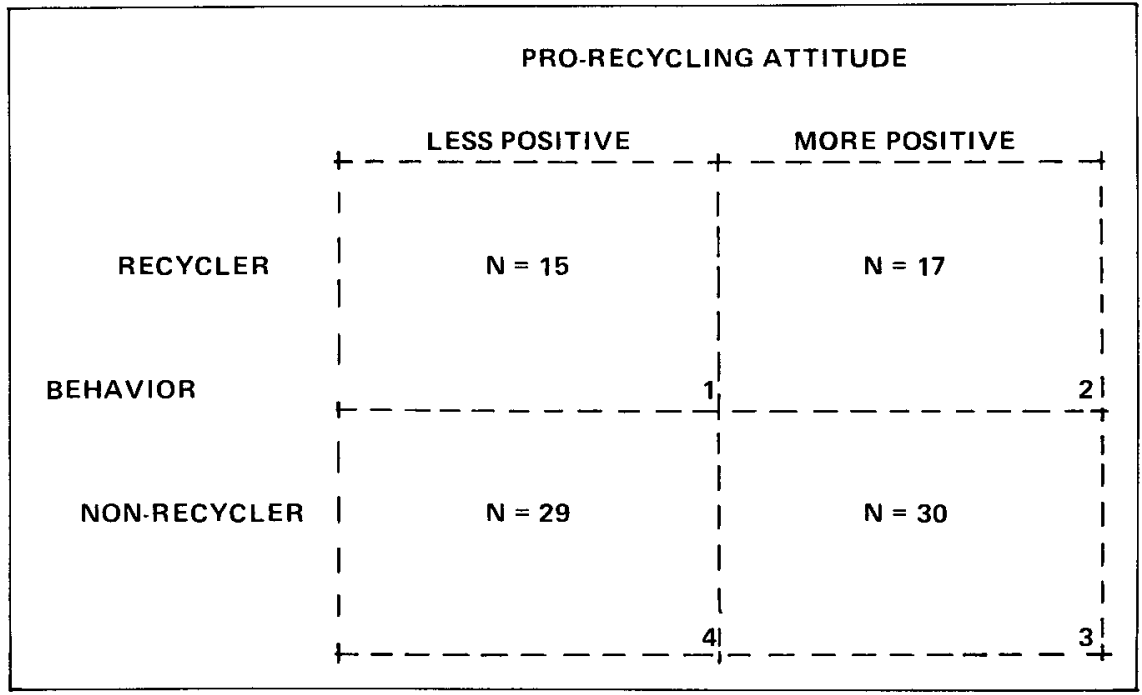

Figure 1. Four groups of respondents-Behavior $X$ Attitude.

Recyclers holding a more positive attitude about the behavior might fit the image of an extremely dedicated conserver. Recyclers with a more positive attitude, when compared to the non-recyclers with a less positive attitude, tend to: 1) derive more satisfaction from frugality, 2) think extrinsic rewards are less appropriate conservation motives, and 3) view the activity as less trivial. Recyclers with a more positive attitude also have the lowest score on the Perceived Difficulty scale-this group of respondents knows exactly what needs to be done to source-separate and recycle their solid waste.

A third cell in Figure 1, the non-recycler with a more positive attitude, may also fit the model that one's attitude about an activity is, in part, the determinant of the behavior. This model expects that a change to a more positive attitude about a behavior will precede the adoption of that behavior. For instance, many resource recovery education programs seek to educate the public about the appropriateness of recycling fully expecting that this will lead to adoption of the behavior. This group of non-recyclers with a more positive attitude is, in a manner of thinking, primed. Thus, the normal progression expected by the attitude-behavior model would first be a change in attitude (movement from cell 4 to 3 in Figure 1) and then the adoption of the behavior (movement from cell 3 to 2 in Figure 1 ).

The scores for this group are particularly interesting. With respect to frugality, extrinsic motivation and trivialness their mean scores are virtually identical to the other "more positive" group suggesting that the attitude, rather 
Table 4. Mean Scores for the Four Groups of Respondents

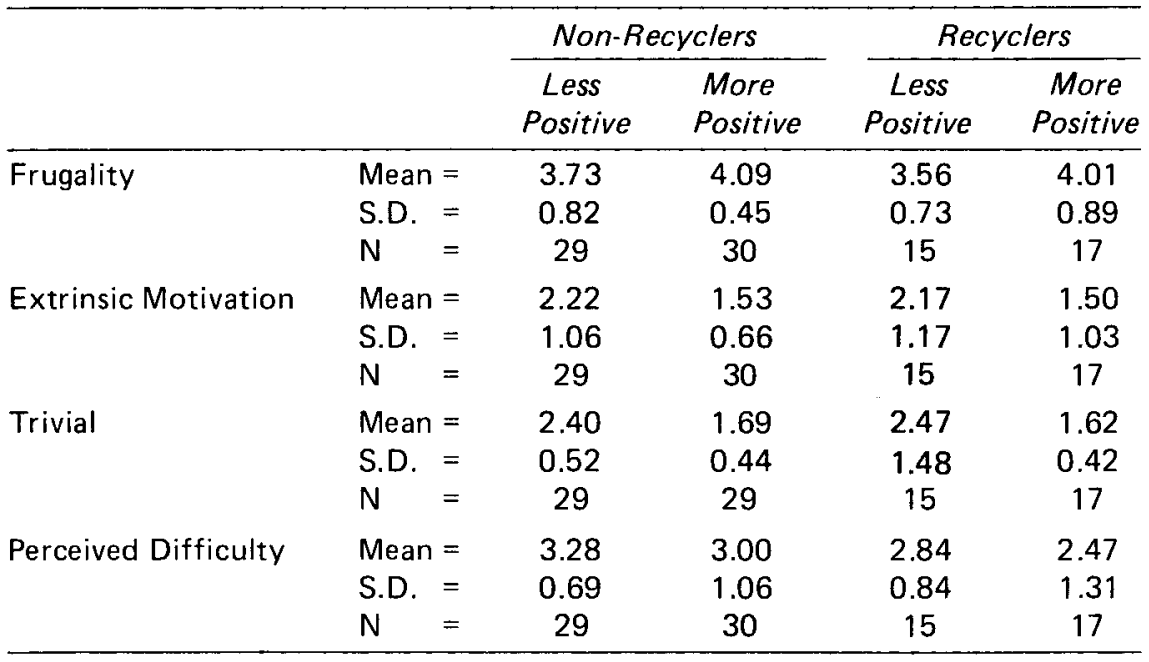

than behavor, is a common pattern. On the Perceived Difficulty scale, however, the patterns reflect a close similarly to their non-recycling cohort.

The fourth group shown in Figure 1 is comprised of respondents who recycle but who also report a less positive attitude about the activity. The attitudebehavior model might not expect this cell to be populated at all. Here one is observing a group of citizens carrying out an admittedly low technology, labor intensive activity about which they currently hold a less positive opinion. A behavior-attitude model might predict that this group's attitude might change, given time, to a more positive opinion. Of course, such a model does not explain why this group was recycling at all.

The fourth group's scores sharply contrast with those of the other group of recyclers: respondents 1) report gaining less satisfaction from frugality, 2) view extrinsic rewards as more appropriate, and 3) view recycling as more of a trivial undertaking. In fact, the scores of recyclers with a less positive attitude are most like those of the group of non-recyclers who hold a less positive attitude except for Perceived Difficulty. The fourth group also differed from the other three in gender makeup ( $29 \%$ women, as opposed to $59 \%$ women in each of the three other groups). This contrast was statistically significant (Chi-Square $=4.35, d f=1, p<.04$ ).

Although an effort was made to interview those household members most involved in recycling, there remains the possibility of a mismatch. For instance, the group of recyclers with a less positive attitude might be made up of respondents who belong to a household that recycles but who are themselves not involved or concerned about the activity. Further research will be needed to disentangle the issue. 


\section{DISCUSSION}

The assumption that recyclers are fundamentally different from non-recyclers is not supported by these data. These two groups were no different with respect to their attitudes about recycling, the degree to which they derive personal satisfaction from frugal actions, their assessment of whether recycling ought to be extrinsically motivated, and the degree to which they view recycling as a trivial activity.

While based on a small sample, these data suggest that respondents view recycling in a very positive light. The opportunity for a resource recovery education program to improve upon the current pro-recycling attitude may then be limited. With little room for improvement, programs might be well advised to concentrate on something other than attitude change. Future programs might consider focusing on helping people to turn their good intentions into actual behavior.

These data also suggest that there may be at least two types of recyclers, each holding different attitudes about the activity. It is interesting to consider what might possess a group of respondents who don't think highly of an activity to nonetheless carry it out. Neither monetary rewards nor the fear of punishment seem strong possibilities. The recycling program studied, like most in the country, lacks both direct monetary incentives and ordinances mandating the behavior. It seems that intrinsic satisfaction is also not a major force, for this group reported the lowest mean score on the satisfaction derived from Frugality scale. There is, however, the possibility of social pressure. Salimando reports that as more and more households on a given block begin to recycle it suddenly becomes embarrassing to not recycle [22]. Thus, one may be observing the concept of "mutual coercion, mutually agreed upon" discussed by Hardin [23] . Hardin indicates that, "To say that we mutually agree to coercion is not to say that we are required to enjoy it, or even to pretend we enjoy it." One needs only to carry out the environmentally appropriate behavior, not be deeply invested in it. This possibility requires further research.

\section{The Role of Information in Promoting Recycling}

"Why don't people recycle more (or at all)?" points up the major issue confronting resource recovery education efforts. It is often assumed that to promote recycling one must explain why people ought to begin recycling. Through persuasion or argument one tries to convince people about the necessity of the behavior. This approach might begin by explaining the magnitude of the problem (e.g., describing how many superdomes of solid waste a city produces each day). Another approach is to explain the threat posed to groundwater supplies by leachate leaking from landfills.

An important, sometimes overlooked, aspect of this education effort involves the error of assuming that once someone knows why he or she should recycle, he 
or she will know exactly how to carry out the behavior. Long time recyclers will say that there is nothing complicated about the activity: people simply have to start doing it. But such experts may forget their early days, the fumbling, confusion, and lack of guidance on how to proceed. The study of human cognition suggests that such a circumstance should not be underrated [24]. Anytime one is not sure what to do next, one is easily overwhelmed. A simple activity becomes a major hassle. This situation may go well beyond the simple lack of information, such as exactly how much space to allocate to the activity, or how much time to allot. It may involve not even knowing what the right questions to ask are. In such a circumstance one is, in essence, incompetent. This can hardly be a state that humans find enjoyable. Humans find it very painful to attempt to function without guidance, without a well developed internal representation. Faced with such a situation people will avoid attempting to begin an activity regardless of their attitudes or opinions.

The non-recycler's higher score on the Perceived Difficulty scale suggests that the issue, in fact, is not why one ought to recycle, but rather how one is to carry out the activity. In other words, resource recovery education programs should concentrate on providing information about how to recycle (e.g., how much space and time to allot to the activity, what can be recycled, how material must be prepared, where to go for assistance). By making recycling seem less of a hassle more households may try the activity for the first time. In summary, it appears that increases in recycling behavior might be attained by helping people to become familiar with how to carry out the activity.

\section{REFERENCES}

1. M. V. Melosi, Garbage in the Cities: Refuse, Reform, and the Environment, 1880-1980, Texas A\&M University Press, College Station, 1981.

2. A. H. Purcell, The Waste Watchers: A Citizen's Handbook for Conserving Energy, Anchor Press/Doubleday, New York, 1980.

3. U.S. Environmental Protection Agency, The Solid Waste Dilemma: An Agenda for Action, Final Report of the Municipal Solid Waste Task Force, Office of Solid Waste, Report EPA/530-SW-88-052, Washington, D.C., 1989.

4. G. W. Allport, Attitudes, in A Handbook of Social Psychology, C. Murchison (ed.), Clark University Press, Worcester, Massachusetts, 1935.

5. L. Festinger, A Theory of Cognitive Dissonance, Row, Peterson, Evanston, Illinois, 1957.

6. K. Thomas (ed.), Attitudes and Behaviour: Selected Readings, Penguin Books, Harmondsworth, England, 1971.

7. L. L. Thurstone, The Measurement of Attitudes, Journal of Abnormal and Social Psychology, 26, pp. 249-269, 1931.

8. J. C. Hendee, No, to Attitudes to Evaluate Environmental Education, Journal of Environmental Education, 3, p. 65, 1972. 
9. R. H. Weigel, Environmental Attitudes and the Prediction of Behavior, in Environmental Psychology: Directions and Perspectives, N. R. Feimer and E. S. Geller (eds.), Praeger, New York, 1983.

10. E. S. Geller, R. A. Winett, and P. B. Everett, Preserving the Environment: New Strategies for Behavioral Change, Pergamon Press, New York, 1982.

11. D. B. Gray, Ecological Beliefs and Behaviors: Assessment and Change, Greenwood Press, Westport, Connecticut, 1985.

12. S. M. Macey and M. A. Brown, The Role of Past Experience in Repetitive Household Behavior, Environment and Behavior, 15, pp. 123-141, 1983.

13. R. H. Weigel, Attitudes and Actions in Research on Environmental Problems, Journal of Resource Management and Technology, 14, pp. 123-129, 1985.

14. R. De Young, Some Psychological Aspects of Recycling: The Structure of Conservation Satisfactions, Environment and Behavior, 18, pp. 435-449, 1986.

15. Encouraging Environmentally Appropriate Behavior: The Role of Intrinsic Motivation, Journal of Environmental Systems, 15, pp. 281-292, 1985-1986.

16. R. De Young and J. Robinson, Some Perspectives on Managing Water Demand: Public and Expert Views, Canadian Journal of Water Resources, 9, pp. 9-18, 1984.

17. L. J. Cronbach, Coefficient Alpha and the Internal Structure of Tests, Psychometrika, 16, pp. 297-335, 1951.

18. J. C. Nunnally, Psychometric Theory, McGraw-Hill, New York, 1978.

19. R. De Young, Clean Michigan Fund 1986-1987 Resource Recovery Education Grants: A Comparison of Selected Programs, Michigan Department of Natural Resources, Lansing, 1987.

20. J. Powell, The Public's Opinion of Recycling, Resource Recycling, 1, pp. 6-7, 1982.

21. Becker Research, New Haven Residents Discuss Recycling, New Haven, Connecticut, 1981.

22. J. Salimando, Camden County Sets the Recycling Pace, Waste Age, pp. 48-49, 51, 53, July 1987.

23. G. Hardin, Tragedy of the Commons, Science, 162, pp. 1243-1248, 1968.

24. S. Kaplan and R. Kaplan, Cognition and Environment: Functioning in an Uncertain World, Praeger, New York, 1982.

Direct reprint requests to:

Raymond De Young

School of Natural Resources

1575 Dana Building

The University of Michigan

Ann Arbor, MI 48109-1115 